\title{
Assessing Team Learning Practices in Project/Design Based Learning Approach
}

\author{
http://dx.doi.org/10.3991/ijep.v6i3.5448 \\ Sivachandran Chandrasekaran, Riyadh Al-Ameri \\ Deakin University, Geelong, Australia
}

\begin{abstract}
Team learning is considered as a constructive way for enhancing students learning in collaborative environment. Team learning involves interaction between students through peer-to-peer learning, which makes students to be a problem solver, an excellent communicator, a good reviewer and a leader. The School of Engineering at Deakin University practices project/design based learning as one of its learning and teaching approach. The project/design based learning process helps students to be self directed leaners which enhances the student learning outcomes towards attaining graduate career expected skills. An Overarching goal of this investigation is assessing the team learning experiences of cohort of students from third year civil undergraduate engineering in a project/design based learning approach at Deakin University. From the students' experiences and views, this study will investigate and visualize the students' choice of team learning practices which enhances their learning outcomes in project/design based curriculum.
\end{abstract}

Index Terms-Team learning, project based learning, design based learning, students perceptions.

\section{INTRODUCTION}

Learning is an active process of investigation and creation based on a learner's interest, experience and curiosity that should result in expanded knowledge and skills. Learning can be conducted and practiced through the support of team learning. Team based learning is student directed approach which enhances student learning experience to acquire team based skills such as communication skill, presentation, time management, knowledge sharing, task management, problem solving and analysing [1-3]. The team-based learning allows students to achieve their common learning objectives by working as a team in a project. From previous literatures, it is clearly mentioned that the majority of the first year medical students experienced team-based learning strategy that enhanced their course learning outcomes [4]. Assessing team-learning practices of students helps an academic to understand their way of approach in working as a team in lab works, design projects, final year project and industry-based projects. It definitely helps to create a comfortable team-learning environment for students who have to acquire graduate ready skills for their future jobs.

Team based learning enhances students learning outcomes through design projects. Design projects have been used to motivate and teach elementary, middle, and high school students. For over a decade, students have been taught different methodologies in the hope of pursuing science and engineering careers. With different learning styles, students are able to express their skills and talents through team based projects or simple design experiments in authentic learning environments[5]. Engineering schools must develop best practice in engineering education to promote student learning and deliver intended graduate outcomes [6].

Based on Engineers Australia (EA) Stage1 competency for professional Engineers, it ensures that effective team membership and team leadership (Element of competency 3.6) is essential for professional engineering graduates. EA states that a professional engineering graduate should understand the fundamentals of effective team dynamics and leadership, work as an effective member or leader of a multidisciplinary team, competent enough to follow timely completion of the task, recognising the value of alternative and diverse viewpoints in a team project, taking initiatives to fulfil the leadership role and respecting the agreed roles of others [7].

This investigation examines students' perceptions of project/design-based learning in their curriculum through an online survey given to a cohort (group) of third year undergraduate engineering students. It also analyses and assesses student perception and preference on team learning practices in project/design based learning. In teambased learning, students work in a group of 4 to 5 team members to brainstorm and find out the solution for a problem or a project. The role of instructor is to facilitate the students to identify objectives of their project and perform problem solving in self-directed learning approach. The role of student is to be an independent performer in a team, joining in team discussions and defend team solutions.

\section{PURPOSE OF ASSESSMENT}

The assessment is the process of gathering and interpreting evidence to make judgements about student learning. The teacher uses assessment methods to assess the learners learning capability according to educational standards. The purpose of assessment is to analyse what students are learning? Why does learning matter to them? What does students produce from their learning? and how well they do it in a study environment?

Assessments need to be regarded as a key professional skill for teachers in a curriculum model. It develops students learning capacity for self-assessment, which makes student to be self-managing and self-reflective. To recognise the complete achievement of students, both on-going formal and informal assessment are mandatory requirements in a unit. Assessment is essential in all engineering courses, which shapes the curriculum by prioritising what is assessed in a learning process.

Sadler [8] reveals that the ultimate goal of providing feedback is to monitor the student learning performance 
continuously. Black and William [9] states that formative assessment will help students to recognise and fulfil the gap between the current level of achievement and desired level of achievement. Some of the literature studies also mentions that feedback is not effective, until the students understands the feedback and applies it in their next learning process. Lorrie A Shepard $[10,11]$ states that academics need help in learning designing assessment according to the content requirements which will develop students classroom learning culture. Mantz Yorke [12] mentions clearly that formative assessment can be formal or informal and also it may either constructive or inhibitory towards learning. Formative assessment is an effective method, which promote student learning across a wide range of curriculum levels.

The purpose of formative and summative assessment were different, literature finding states that the feedback process of a formative assessment will help learning process to close the knowledge gap acquired in a summative assessment process. Students need to acquire new knowledge and skills in their learning by engaging in selfassessment as a regular on-going process. In addition to student learning, assessment will help academics to examine and improve teaching practices. Lorrie A Shepard suggest that formative assessment is the best way for teachers to make their assessment visible to students [10]. The self-directed learners are more effective in acquiring knowledge and they are confident in achieving enhanced learning outcomes. When the students are more self directed learners, they are less dependent on academic support during the learning process [13]. Several studies mentioned that when academics use formative assessment in classroom, students gain substantial learning [14-16].

Over the year's, Deakin views on assessment such as it is used to engage students in learning and being productive. Both the leaners and teachers are part of the learning process and the assessment methods with timely feedbacks. Deakin places assessment as a centre of subject and program design, whenever possible it is also focused on staff and institutional development. Students are engaged using various effective assessment methods in the classroom. The effective assessment methods are authentic assessment, self and peer assessment, and assessment as evidence.

- In authentic assessment, students work towards the activities, which fulfils the intended course learning outcomes.

- In self and peer assessment, students work in teams and collaborative with each other in project emphasis the development of their shared and peer reviewed learning skills.

- Assessment in evidence, students need to practice and achieve course-learning outcomes, which derives the evidence for achievement of awards.

\section{METHODOLOGY}

Online survey is performed on students enrolled in the unit 'Reinforced Concrete Structures (SEV353)' in T22015. The assessment tasks for SEV353 are one design project $(30 \%)$, one laboratory report $(15 \%)$, and final examination $(55 \%)$, hence considered as partial DBL unit. However, the assessment tasks for full DBL unit in Civil engineering are based on $100 \%$ design projects. The varia- ble level of involvement of the design based learning approach in the teachings of this unit will help the lecturers to assess the students' satisfaction based on the adopted level of design based learning approach. It also helps to analyse and assess the level of students' preference in team learning. The partial DBL unit has project component that is not exceeding $30 \%$ and complied with $70 \%$ final exam and the full DBL approach is assessed on $100 \%$ of project component. The idea behind this partial DBL is to examine the relevant theoretical knowledge of students. The comparison of partial DBL and full DBL is shown in table I below.

The cohort of student involved in this online survey has exposed to two different criteria for group forming. For the lab component of the unit students are participating in forced groups selected by the lecturer (teaching staff) while in the design project group students participating on

TABLE I.

COMPARISON OF PARTIAL DBL AND FULL DBL

\begin{tabular}{|c|c|}
\hline & Partial DBL \\
\hline Assessment & \\
\hline $\begin{array}{l}\text { *One Design project }(30 \% \\
\text { Concrete lab }(15 \%) \\
\text { *Final examination }(55 \%)\end{array}$ & laboratory project - \\
\hline Contact & \\
\hline $\begin{array}{l}* 3 \times 1 \text { hour Class per week } \\
* 1 \times 1 \text { hour Seminar per we } \\
* 3 \times 3 \text { hour Laboratory }\end{array}$ & \\
\hline Teaching & \\
\hline $\begin{array}{l}\text { *Content driven, focused } \\
\text { Student driven design wo } \\
\text { *Assessment based on grc }\end{array}$ & $\begin{array}{l}\text { Fundamental \&Theory } \\
\text { k \& individual work }\end{array}$ \\
\hline Project Activities & \\
\hline $\begin{array}{l}\text { *For a multi storey reside } \\
\text { carry out) }\end{array}$ & ilding (students have to \\
\hline Group Task $-20 \%$ & Individual Task $-80 \%$ \\
\hline $\begin{array}{l}\text { *Conceptual design } \\
\text { report } \\
\text { *Structural analysis }\end{array}$ & $\begin{array}{l}\text { *Work on detailed design } \\
\text { for continuous beams }\end{array}$ \\
\hline & Full DBL \\
\hline Assessment & \\
\hline $\begin{array}{l}* \text { Design project } 1(50 \%) \\
* \text { Design project } 2(50 \%)\end{array}$ & \\
\hline Contact & \\
\hline $\begin{array}{l}* 1 \times 2 \text { hour Class per wee } \\
* 1 \times 2 \text { hour Design studio }\end{array}$ & \\
\hline Teaching & \\
\hline $\begin{array}{l}\text { *More on practice } \\
\text { *Design work } \\
\text { *Design Briefs } \\
\text { *Assessment based on } \mathrm{Gr}\end{array}$ & $\mathrm{k} \&$ individual work \\
\hline Project Activities & \\
\hline $\begin{array}{l}\text { *For a multi storey office } \\
\text { carry out) }\end{array}$ & (students have to \\
\hline Report 1 & \\
\hline Group Task $-20 \%$ & Individual Task $-80 \%$ \\
\hline $\begin{array}{l}\text { *Conceptual design for } \\
\text { columns } \\
\text { *Structural analysis for } \\
\text { columns }\end{array}$ & $\begin{array}{l}\text { *Detailed design for five } \\
\text { columns in a selected floor }\end{array}$ \\
\hline Report 2 & \\
\hline Group Task 20\% & Individual Task $-80 \%$ \\
\hline $\begin{array}{l}\text { *Conceptual design for } \\
\text { shear walls \& footings } \\
\text { *Structural analysis for } \\
\text { shear walls \& footings }\end{array}$ & $\begin{array}{l}\text { *Detailed design for a } \\
\text { selected shear walls \& } \\
\text { footings }\end{array}$ \\
\hline
\end{tabular}


selected group (students form their own groups). This is an ideal opportunity for the lecturers to receive student feedbacks on group forming while the same cohort (group) experience two different pattern in the same unit in the same offering trimester with same teaching staff. Thus all the variables were kept constant expect the group pattern.

The online survey is online based which was conducted by a third person who is not involved in this investigation. The survey was given to more than 50 students' in $3^{\text {rd }}$ year engineering. The questions were prepared to identify the challenges and issues in team learning and in particular to investigate the student's perspective on the team grouping, student participation in a group task, group pattern helps students to develop learning objectives, students preference on sharing task in a team. The survey questions used in this investigation are shown below in various modules

Module 1: Questions 1 to 3 are quantitative questions focus on design-based learning and in particular focus around project/design-based learning approach. These questions are designed to analyse students' preference and level of satisfaction on design based learning approach.

Module 2: Questions 4 to 7 are quantitative questions, which focused on students' preference on contact hours between formal lectures and design class, assessment on partial DBL (30\% project/ $70 \%$ exam) and Full DBL (100\% project).

Module 3: Questions 8 to 12 are designed to acquire students experience on grouping, composition of group, group size and estimation of each team member participation in a group.

Module 4: questions 13 to 16 is exploring about student perceptions regarding role of a team member, developing learning objectives and benefits based on group pattern and sharing task in a group.

\section{RESUlts/DiscUSSION}

The purpose of analysing students' views in learning and teaching is one of the ways for staff to evaluate and develop their academic performance. The academic performance and professional development will help to ensure the course learning outcomes and standards, which are aligned with Deakin Graduate Learning Outcomes, professional accreditation requirements and relevant Australian Qualifications Framework specifications. These survey questions are based on quantitative analysis.

Unlike Problem Based Learning (PBL) and Project Based Learning (PjBL), DBL is a self-directed learning approach and opens up learning activity so design skills must be learnt and applied [17]. Students must locate the resources required, and analyse any needs in order to create a design [18]. This method gives students the freedom to apply their design skills as they think best. DBL not only looks at the end product but also at the underlying process in creating that product [19]. Design based learning (DBL) is a self-directed approach in which students initiate learning by designing creative and innovative practical solutions which fulfill academic and industry expectations.

\section{A. Students Perspectives on Team Learning in Project/Design Based Curriculum}

Module 1: The student views on practising DBL is $30 \%$ project $/ 70 \%$ exam in this particular unit involved in the research. The ultimate goal is to determine the students' perspectives of practising team learning in DBL and the perspectives changes over the years studying engineering. Figure 1 shows around $78 \%$ of students mentioned that practicing DBL approach is helpful, necessary and it is necessary in their learning too where as $22 \%$ says practicing DBL possibly helps. It clearly shows that the cohort of students likes to involve more on design activities through projects.

From the analysed results above, about $100 \%$ of students in favour of DBL in this particular unit (subject/course) which supports the implementation of this approach to delivery engineering materials. It is worth analysing students perceptions on delivery of a leaning and teaching approach. The results (figure 1) show there is no negative opinion about this approach from this cohort of students. Students are divided equally between both partial DBL and full DBL approaches.

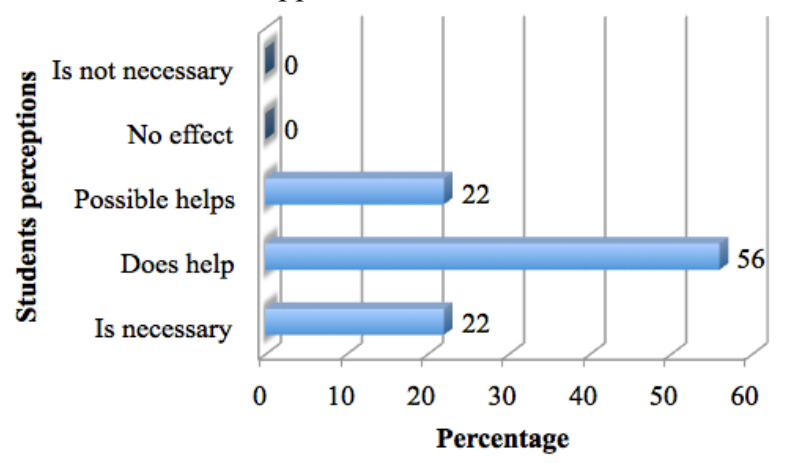

Figure 1. Students' views on practicing design based learning approach

TABLE II.

STUDENTS' PREFERENCE ON DESIGN BASED LEARNING MODE

\begin{tabular}{|l|c|}
\hline \multicolumn{1}{|c|}{ Students' perceptions } & $\mathbf{\%}$ \\
\hline Partial DBL $(30 \%$ project / 70\% Exam) & 42 \\
\hline Full DBL $(100 \%)$ & 58 \\
\hline
\end{tabular}

As it is clearly shown from Table II, $42 \%$ of students preferred partial DBL and 58\% preferred full DBL mode. From those perceptions of students, it explains their experience on partial DBL is comfortable for their learning and they are expecting their learning around full DBL. As mentioned above, the cohort of students involved in this survey is experienced on partial DBL ( $3^{\text {rd }}$ year) and the same cohort will experience full DBL in final year. Table II reflects that there is favour of partial DBL preferred assessment, which depends on definite product (final exam). However the other group, they are in favour of focusing on project only.

Figure 2 discusses about the students level of satisfaction in DBL delivery in their selected mode. It shows that about $45 \%$ of $3^{\text {rd }}$ year civil engineering students are satisfied with the way of DBL delivered and $55 \%$ of students mentioned their experience as neutral, which is a partial satisfaction in the delivery method. It is a good chance for academics to analyse these students experience in $3^{\text {rd }}$ year and it changes their teaching approach in future according to student expectations. From figure 2 students satisfaction on DBL approach confirms that the benefits of implementing of this approach in engineering education. However, reasonable numbers of students (about $45 \%$ ) are in favour of the DBL approach. 


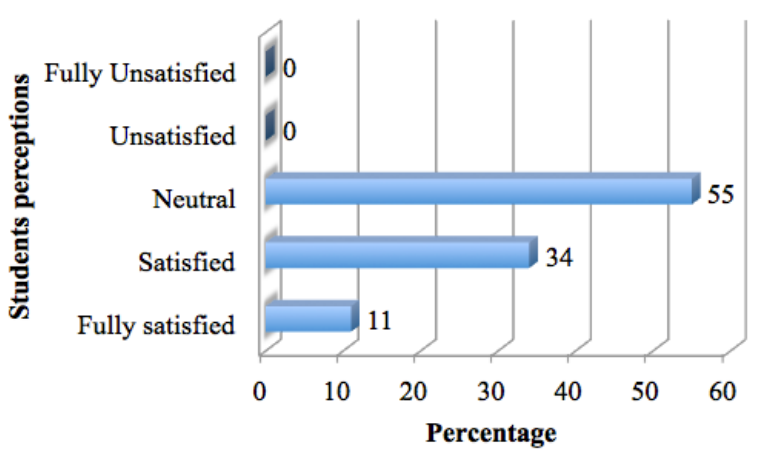

Figure 2. Students' level of satisfaction in DBL delivery in selected DBL mode (based on question above)

Module 2: Students experienced formal lectures in the traditional way of teaching for a long time. The curriculum enhancement towards project based and design focused environment is giving a different experience to students. It was interesting to see students' preference, when the students are asked about dividing the contact hours between formal lectures and design class.

Table III clearly shows that $67 \%$ of students preferred $50 \%$ lecture/ $50 \%$ design class, which deliberately explains that students need the unit content to be discussed before they start working on project/design. It is also interesting to see that $22 \%$ of students preferred $30 \%$ lectures/ $70 \%$ design class and another $11 \%$ prefers $0 \%$ lecture and $100 \%$ design class. This proportion shows combination of different categories of students in a classroom. In respect to the need of supporting the students learning, from the analysed results it mentioned that about two third of students' (table III) confirms that there is a need to provide sufficient theoretical background to support their project work.

Table IV and Table V show remarkable views of students' preference on assessment for partial DBL and full DBL. Table IV illustrates that around $34 \%$ of students preferred $100 \%$ project $/ 0 \%$ exam, $11 \%$ of students favoured $50 \%$ project $/ 50 \%$ exam, $28 \%$ of students prefers $30 \%$ project $/ 70 \%$ exam and $30 \%$ of students preferred $70 \%$ project $/ 30 \%$ exam. From these different students perspectives, it is interesting to look at students' preference of $100 \%$ project in partial DBL, which the students believe it enhances student-learning outcomes through projects. The remaining students believed in combination of project and exam will help them for a formal assessment. Previous study evidencing hat projects are better way of teaching students in an engineering curriculum [20, 21]. Table V clearly explains students' preference on assessment for full DBL mode. Most of the students (around $58 \%$ ) preferred 10\% Proposal, 30\% E-portfolio and 60\% Project, which shows that students have an adequate expectation on assessment criteria towards learning outcomes.

Assuming that the assessment for partial DBL will be a combination of project and exam, about $70 \%$ students (table IV) preferred this sort of assessment (project and exam). On the other side, only $30 \%$ are in favour of assessment based on project. The combined assessment is the format suitable for partial DBL approach in this unit. Assuming that the assessment for full DBL is based on combination of project proposal, e-portfolio and project. Most of the students (table V) preferred to have large in- fluence for final project rather than the project proposal or e-portfolio.

The project/design-based learning is focused on enhancing students learning by performing design activities around the project. Most of the students' perception on exam is an indication of their previous and current experience of traditional curriculum [22-24]. Now it is academic responsibility to guide the students towards self directed learning practice that certainly make the students as career ready graduates $[25,26]$. Assessment plays a vital role on students learning and teaching process. Based on assessment, the students are assessed their level of competency and achievement in acquiring the learning outcomes mentioned in Stage 1 competency of Engineers Australia [7]. The students' perceptions on teaching effectiveness are evaluated in many ways. Evaluating students' preference on group assessment and grouping will give academics which type of team learning practice is suitable for their learning.

TABLE III.

STUDENTS' PREFERENCE ON DIVIDING CONTACT HOURS BETWEEN FORMAL LECTURES AND DESIGN CLASS

\begin{tabular}{|l|c|}
\hline \multicolumn{1}{|c|}{ Students' perceptions } & $\mathbf{\%}$ \\
\hline $0 \%$ lecture / $100 \%$ design class & 11 \\
\hline $30 \%$ lecture / $70 \%$ design class & 22 \\
\hline $50 \%$ lecture / $50 \%$ design class & 67 \\
\hline $70 \%$ lecture / $30 \%$ design class & 0 \\
\hline $100 \%$ lecture / $\%$ Design class & 0 \\
\hline
\end{tabular}

TABLE IV.

STUDENTS’ PREFERENCE ON ASSESSMENT FOR PARTIAL DBL MODE

\begin{tabular}{|l|c|}
\hline \multicolumn{1}{|c|}{ Students' perceptions } & $\%$ \\
\hline $0 \%$ project $/ 100 \%$ exam & 0 \\
\hline $10 \%$ project / $90 \%$ exam & 0 \\
\hline $30 \%$ project / $70 \%$ exam & 28 \\
\hline $50 \%$ project / $50 \%$ exam & 11 \\
\hline $70 \%$ project / $30 \%$ exam & 30 \\
\hline $90 \%$ project / $10 \%$ exam & 0 \\
\hline $100 \%$ project / $\%$ exam & 34 \\
\hline
\end{tabular}

TABLE V.

STUDENTS' PREFERENCE ON ASSESSMENT FOR FULL DBL MODE

\begin{tabular}{|l|c|}
\hline \multicolumn{1}{|c|}{ Students' perceptions } & $\mathbf{\%}$ \\
\hline $10 \%$ proposal, 30\% e-portfolio and $60 \%$ project & 58 \\
\hline $15 \%$ proposal, $25 \%$ e-portfolio and $60 \%$ project & 28 \\
\hline $25 \%$ proposal, $25 \%$ e-portfolio and $50 \%$ project & 14 \\
\hline $30 \%$ proposal, 30\% e-portfolio and $40 \%$ project & 0 \\
\hline $40 \%$ proposal, 30\% e-portfolio and 30\% project & 0 \\
\hline
\end{tabular}

TABLE VI.

STUDENTS’ PREFERENCE ON PROJECT ASSESSMENT

\begin{tabular}{|l|c|}
\hline \multicolumn{1}{|c|}{ Students' perceptions } & $\mathbf{\%}$ \\
\hline $0 \%$ group (peer assessment) $/ 100 \%$ individual & 11 \\
\hline $20 \%$ group (peer assessment) $/ 80 \%$ individual & 55 \\
\hline $50 \%$ group (peer assessment) $/ 50 \%$ individual & 33 \\
\hline $80 \%$ group (peer assessment) $/ 20 \%$ individual & 0 \\
\hline $100 \%$ group (peer assessment) $/ 0 \%$ individual & 0 \\
\hline
\end{tabular}


Table VI discusses about student preference on project assessment, where $55 \%$ prefers $20 \%$ group / $80 \%$ individual assessment, another $33 \%$ preferred $50 \%$ group / 50\% individual and only $11 \%$ mentioned $0 \%$ group / $100 \%$ individual assessment. The student's perceptions clearly shows that assessment should be based more on their individual work when compared to team based work. From Table 6, it shows that the project assessment will be based on mixed group and individual task. Around $90 \%$ of students are in favour of having a large share $(50 \%-80 \%$ of total marks) of assessment on the individual task. Hence the recommended assessment for this unit is $20 \%$ group / $80 \%$ individual.

Module 3: Table VII shows students preference on number of team members in a team and how grouping should be performed. Around $44 \%$ of students preferred to be 3 in a group, 45\% mentioned 5 students in a group where as $78 \%$ preferred to be group by student own preference and $11 \%$ preferred to group randomly. Table VII also shows that only $11 \%$ of students preferred to work individually and table 6 shows $11 \%$ of students preferred $100 \%$ individual assessment. Overall student perceptions say that working individually and assessed individually is the most appropriate way to be preferred [27]. The difference between on-campus and off-campus students perception is mainly based on their learning experience. It is important to have a decent composition of on-campus and off-campus students in a team working on a project.

Table VIII shows students preference on composition of group with respect to on-campus and off-campus, about $55 \%$ students preferred to be on-campus only and offcampus only categories but it is interesting to see $34 \%$ of students preferred 1-2 off campus students in an oncampus group and $11 \%$ mentioned $50 \%$ of on-campus / off-campus students in a team.

When looking at the group pattern and forming in this unit (table VIII), around $90 \%$ of students' preferred to have a moderate size (3-5 students) in a group, which help them to communicate effectively and control the project task. With respect to group forming procedure, about $80 \%$ of students preferred to form their own grouping rather than forced grouping by academics or by any other pattern such as alphabetical order, group randomly, group in sequence.

With respect to group composition for Deakin engineering cohort of students in which large number (around $30 \%$ ) of off-campus students are aboard in this particular unit. From previous unit delivery, off-campus students are failed to communicate effectively with on-campus counter part in the same group. Therefore this survey results (table VIII) reflects that the students preferred to have one category (only on-campus / only off-campus) in the group. This option will help students' to organize meeting, communicate more frequently working in a project. There is a mismatch of availability of both on-campus and offcampus cohorts. While the rest of students think that having a mix composition of group will help them to share the task, knowledge and experience. The third year students are also asked about their satisfaction on their current group size in lab groups and design project group. In $3^{\text {rd }}$ year unit, academic group students in a lab work and students are grouped by their own selection in a design project.
TABLE VII.

STUDENTS' PREFERENCE ON GROUPING

\begin{tabular}{|l|c|}
\hline \multicolumn{1}{|c|}{ Students' perceptions } & $\%$ \\
\hline On campus / off campus only (only one category) & 55 \\
\hline $1-2$ off campus students in an on campus group & 34 \\
\hline $1-2$ on campus students in an off campus group & 0 \\
\hline $50 \%$ of off campus / on campus students & 11 \\
\hline
\end{tabular}

TABLE VIII.

STUDENTS' PREFERENCE ON COMPOSITION OF GROUP WITH RESPECT TO OFF CAMPUS / ON CAMPUS

\begin{tabular}{|l|c|}
\hline \multicolumn{1}{|c|}{ Students' perceptions } & $\%$ \\
\hline 1 (individual only) & 11 \\
\hline 3 students in a group & 44 \\
\hline 5 students in a group & 45 \\
\hline 7 students in a group & 0 \\
\hline Group randomly & 11 \\
\hline Group by alphabetical order & 0 \\
\hline Group by student own preference & 78 \\
\hline Focus group based on academic performance & 11 \\
\hline
\end{tabular}

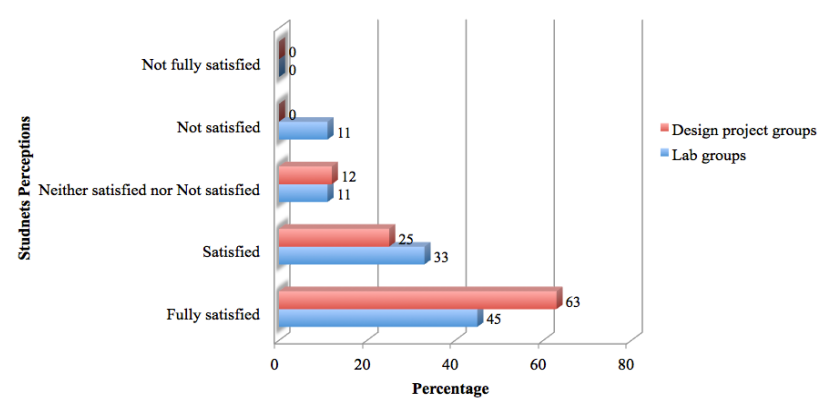

Figure 3. Students' views on group size

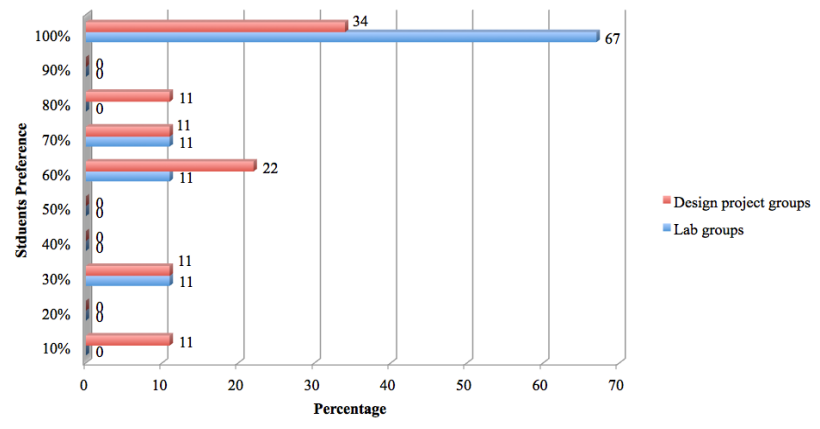

Figure 4. Students' self estimation on participation in a group task

Figure 3 shows around $88 \%$ of students are satisfied with their group size in design projects and around $78 \%$ of students are satisfied with their lab group. Only $11 \%$ of students are not satisfied with their group size. Based on their group size satisfaction, Figure 4 shows students selfestimation on participation in a group task. About $67 \%$ in lab group and 34\% in design project group estimates $100 \%$ of participation in a group task, $11 \%$ in lab group and $11 \%$ in design project group estimates $70 \%$ of participation in a group task and $11 \%$ in lab group and $22 \%$ in design project group estimates $60 \%$ of participation in a group task. It is clearly shown that $14-90 \%$ of students in lab group performing $60-100 \%$ of participation which defines that students are involved in lab work where lab task to be finished for continues assessment and knowledge sharing. 
In design project, $11-35 \%$ of students performing $60-100 \%$ of participation, which defines that those students are relied on other team members' effort to finish a complete project.

With respect to group forming procedure and as described above in figure 4 , this cohort of students participated in two different assessment task (lab group and design project group) following two different group patterns. For lab group, groups are forced by the unit chair (lecturer) and for design project; students select their own group. This helps students to isolate the effect of group forming from other variables in this study. In lab work, students need to be work based on guidelines provided for their task but in design project students need to work with other team members to share their ideas, brainstorming, finalising outcome to finish the task. From the results around $75 \%$ (figure 4 ) of students are satisfied with group forming pattern. The recommendation for this unit is that the group-forming pattern shall be based on the type of task for the group whether it is physical work in the lab or theoretical work in the classroom.

Module 4: Based on the above selection, Table IX discuses about the reason for students selection on selfestimation of participation in a group work. Most of the students (around 70-100\%) in lab group and design project group says that they are familiar with the group members and communicate well, having ability to follow task instructions, having enough time and enough cooperation in the group. Students are concerned about other team members who are not performing enough cooperation in both lab group and design project group. The students in design project group also mentioned that the task is complicated.

Based on their selection of self-estimation of participation in a group and appropriate reason for it. Figure 5 shows around $71 \%$ of students in deign project group and $42 \%$ of students in lab group students preferred to agree that there is need for group leader to manage, discuss and perform task in a group. In design project group, 14\% students say that it is must to have a leader for a group. On the other side, $58 \%$ in lab group mentioned that there is no need of a group leader.

Students also asked about their preference on a kind of role in a group, figure 6 discusses this interesting data; most of the students (about 67\%) in lab group and in design project group wants to be a communicator, $11 \%$ prefers to be a quite performer in both groups but it is interesting that $22 \%$ of students in lab group preferred to be leader. The findings from the past research performed by the industry indicate that learning is a combined source of students' own initiation to social, global responsibility and the expected skills from the industry. The industry is looking for graduates who are ready to practice and perform the essential competences such as practical knowledge, problem solving, teamwork, and innovative and creative designing of real-world projects [28-30].

As mentioned before, the cohort of students involved in this unit are grouped by the lecturer in lab group and grouped by student own preference in design project group. The students mentioned their experience on group pattern that develops their learning objectives and benefits from the task. Figure 7 shows about $58 \%$ of students are satisfied with preference of own select in design project group and $44 \%$ of students are satisfied with forced group in lab work. $14 \%$ of students said that it is very good op-
TABLE IX.

STUDENTS' PREFERENCE ON COMPOSITION OF GROUP WITH RESPECT TO OFF CAMPUS / ON CAMPUS

\begin{tabular}{|l|c|c|}
\hline \multicolumn{1}{|c|}{ Students' perceptions } & $\begin{array}{c}\text { Lab } \\
\text { Group } \\
\mathbf{( \% )}\end{array}$ & $\begin{array}{c}\text { Design } \\
\text { Project } \\
\text { Group } \\
\mathbf{( \% )}\end{array}$ \\
\hline Task is complicated & 0 & 22 \\
\hline Not enough cooperation in the group & 11 & 22 \\
\hline I have no time for the group task & 11 & 0 \\
\hline I don't have the ability to follow task instructions & 0 & 0 \\
\hline $\begin{array}{l}\text { I am not familiar with group members and hence } \\
\text { cannot communicate well }\end{array}$ & 11 & 11 \\
\hline $\begin{array}{l}\text { I am familiar with group members and I can } \\
\text { communicate well }\end{array}$ & 55 & 66 \\
\hline I have the ability to follow task instructions & 55 & 55 \\
\hline I have enough time for the group task & 44 & 44 \\
\hline There is enough cooperation in the group & 55 & 66 \\
\hline
\end{tabular}

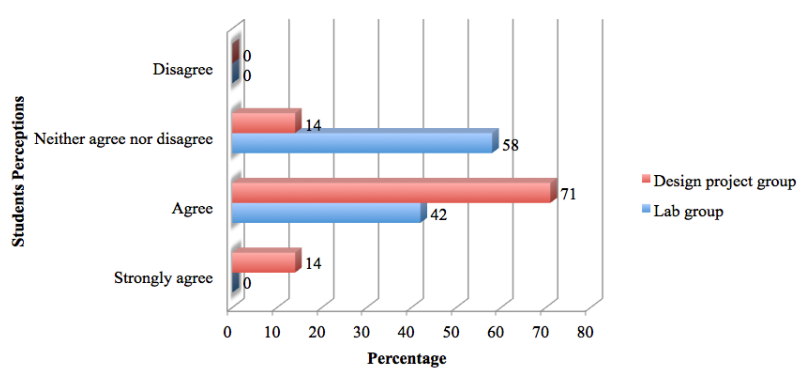

Figure 5. Students' view on group leader is essential for a group

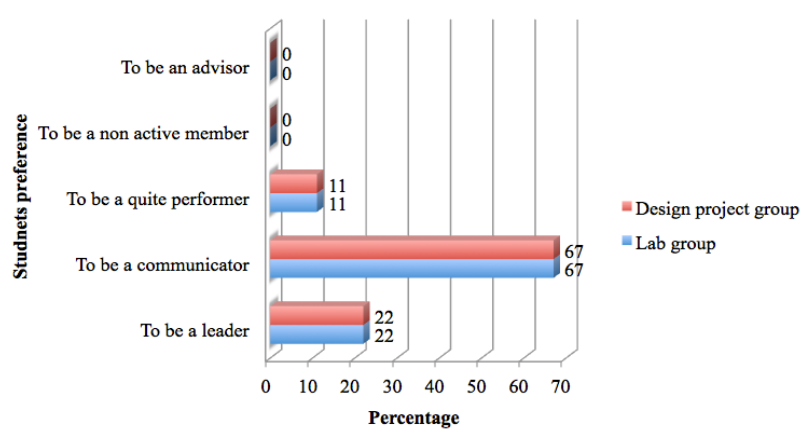

Figure 6. Students' preference on kind of role in a group

tion of having own select pattern in project group and forced pattern in lab group. Overall students' experiences shows that they are much concerned about grouping option in lab group rather than design project group. The reason behind this concern is, because students want to undertake $100 \%$ responsibility in design project where self-directed learning takes place. When an academic look at the students' preference on sharing the task within group/team members, Table X explains that $72 \%$ of students in design project and $28 \%$ of students in lab group want to share the same task within a team. On the other side, $57 \%$ in design project and $42 \%$ in lab group want to divide the task between the groups in a group work.

In respect to student participation in the group task for lab group (forced group) and design project group (on select group), Figure 4 shows that most of the students are happy with their participation which is rated between $80 \%-100 \%$. The main reason for those results, the students 
have sufficient time to assess and understand to carry out their project. Most of the students in this cohort preferred to have a leader but they don't want to be leader in a group (figure $5 \& 6$ ). The reason for this, Students in a group will still requires a clear instructions (guidelines \& roadmap) which leads the students to complete the task, develops learning objectives and benefits from the task. Students preferred to be working as a team in as design project but not in the lab project or task.

However about $42 \%$ (table X) of students preferred group work in the lab component, which will lead to conclude that the group-forming pattern shall be based on the type of task for the group whether it is physical work in the lab or theoretical work in the classroom.

\section{CONCLUSION}

The focus of this paper is to analyse and assess cohort of students' perspectives on team learning practices in project/design based learning approach. From analysed survey results, it shows students in third year civil engineering (undergraduate) have an adequate experience on project/design-based learning. From the students' experiences and views, this study investigated and visualized the students choice of a unique team learning practice which enhances their learning outcomes in project/design based curriculum. The results summarizes that $100 \%$ of students in favour of DBL, more than $50 \%$ of students' are satisfied with DBL delivery method, students preferred a combined assessment is the format suitable for partial DBL approach in this unit and most of the students preferred to have large weight for final project in full DBL. The students also mentioned that the recommended assessment for this unit is $20 \%$ group / $80 \%$ individual with a moderate size of $3-5$ students in a group. With respect to group forming procedure, about $80 \%$ of students preferred to form their own grouping rather than forced grouping by academics. In regards to composition of group, the students preferred to have one category (only on-campus / only off-campus) in the group that will help students' to organize meeting, communicate more frequently working in a project. The results also states that group-forming pattern shall be based on the type of task for the group whether it is physical work in the lab or theoretical work in the classroom. Overall investigation discussed about students' perceptions on team learning practices in project/design based learning. This unique team learning practice shows this cohort of students' preference on the team grouping, student participation in a group task, group pattern helps them to develop learning objectives and benefits from the task.

\section{REFERENCES}

[1] C.C. Chan, C. Pearson, and L. Entrekin, "Examining the effects of internal and external team learning on team performance", Team Performance Management: an international journal, vol. 9(7/8), pp. 174-181, December 2003.

[2] H. Julie Yazici, "A study of collaborative learning style and team learning performanc”, Education+ Training, vol.47(3), pp. 216229, April 2005.

[3] I.J. Quitadamo, C.J. Brahler, and G.J. Crouch, "Peer-Led Team Learning: A Prospective Method for Increasing Critical Thinking in Undergraduate Science Courses", Science Educator, vol.18(1), pp. 29-39, April 2009.

[4] P.G. Koles, A. Stolfi, N.J. Borges, S. Nelson, and D.X. Parmelee, "The impact of team-based learning on medical students' academic performance", Academic Medicine, vol.85(11), pp. 1739-1745, November 2010. http://dx.doi.org/10.1097/ACM.0b013e3181 f52bed

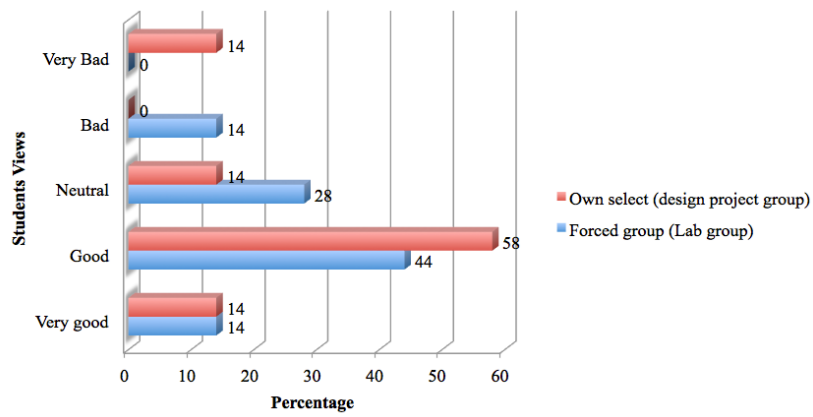

Figure 7. Students' views on group pattern that develops learning objectives and benefits from the task

TABLE X.

STUDENTS' PREFERENCE ON SHARING THE TASK WITH GROUP/TEAM MEMBERS

\begin{tabular}{|l|c|c|}
\hline \multicolumn{1}{|c|}{ Students' perceptions } & $\begin{array}{c}\text { Lab group } \\
\text { (\%) }\end{array}$ & $\begin{array}{c}\text { Design project } \\
\text { group (\%) }\end{array}$ \\
\hline $\begin{array}{l}\text { Sharing the same task within } \\
\text { the team (team work) }\end{array}$ & 28 & 72 \\
\hline $\begin{array}{l}\text { Divide the task between the } \\
\text { group (Group work) }\end{array}$ & 42 & 57 \\
\hline
\end{tabular}

[5] J. E. Froyd, P.C. Wankat and K.A. Smith, "Five Major Shifts in 100 years of Engineering Education", Proceedings of the IEEE (special centennial issue), pp.1344-1360, May 2012. http://dx.doi.org/10.1109/jproc.2012.2190167

[6] R. Goldsmith, C. Reidsema, H. Beck, D. Campbell, "Perspectives on teaching and learning in Engineering Design across four universities", in 2nd International conference on design education(ConnectED2010), The University of New South Wales, 2010.

[7] EA, "Stage1 competency standard for professional engineer", Engineers Australia: Australia, 2012.

[8] D.R. Sadler, "Formative assessment and the design of instructional systems", Instructional science, vol.18(2), pp. 119-144, June 1989. http://dx.doi.org/10.1007/BF00117714

[9] P. Black, and D. Wiliam, "Assessment and classroom learning", Assessment in education, Vol.5(1), pp. 7-74, March 1998. http://dx.doi.org/10.1080/0969595980050102

[10] L.A. Shepard, "The role of assessment in a learning culture", Educational researcher, Vol.29(7), pp. 4-14, October 2000. http://dx.doi.org/10.3102/0013189X029007004

[11] L.A. Shepard, and L.A. Sheppard, "The role of classroom assessment in teaching and learning", 2000.

[12] M. Yorke, "Formative assessment in higher education: Moves towards theory and the enhancement of pedagogic practice", Higher education, vol.45(4), pp. 477-501, June 2003. http://dx.doi.org/10.1023/A:1023967026413

[13] D.J. Nicol, and D. Macfarlane-Dick, "Formative assessment and self-regulated learning: A model and seven principles of good feedback practice", Studies in higher education, vol. 31(2), pp. 199-218, April 2006. http://dx.doi.org/10.1080/03075070600 $\underline{572090}$

[14] J. Hattie, and H. Timperley, "The power of feedback", Review of educational research, vol.77(1), pp. 81-112, March 2007. http://dx.doi.org/10.3102/003465430298487

[15] P. Black, and D. Wiliam, "Developing the theory of formative assessment. Educational Assessment, Evaluation and Accountability", (formerly: Journal of Personnel Evaluation in Education), vol.21(1), pp. 5-31, February 2009.

[16] D. Boud, "Enhancing learning through self-assessment", Routledge, October 2013.

[17] J. Perrenet, A. Aerts, J. Van der Woude, "Design Based Learning in the Curriculum of Computing Science - a Skillful Struggle", in proceedings of Interational Conference on Engineering Education, pp.21-23, July 2003. 
[18] N. Iwane, H. Ueda, and M. Yoshida, "Design based learning by knowledge reuse: Towards its application to e-learning", in Information Reuse and Integration (IRI), 2011 IEEE International Conference on. Pp.468-473, August 2011. http://dx.doi.org/10.1109/iri.2011.6009593

[19] W. Wijnen, "Towards design-based learning", Educational Service Centre, 1999.

[20] S. Chandrasekaran, A. Stojcevski, G. Littlefair and M. Joordens, "Learning through Projects in Engineering Education", in Eurpean Journal of Engineering Education Conferences (SEFI 2012), Thessaloniki, Greece, 2012.

[21] S. Chandrasekaran, A.M. Oo, A. Stojcevski and G. Littlefair, "Best assessment practices of final year engineering projects in Australia", pp.1-17, University of Technical Education, Ho Chi Minh City, 2013.

[22] R.M. Shet, N.C. Iyer, P.C. Nissimgoudar and S. Ajit, "Integrated Experience: Through Project-Based Learning", in Proceedings of the International Conference on Transformations in Engineering Education, Springer India, 2015. http://dx.doi.org/10.1007/978-81322-1931-6 55

[23] B. Johnson and R. Ulseth, "Professional competency attainment in a project based learning curriculum: A comparison of project based learning to traditional engineering education", in Frontiers in Education Conference (FIE), 2014 IEEE. 2014. http://dx.doi.org/10.1109/fie.2014.7044124

[24] K. Jeon, O.S. Jarrett, and H.D. Ghim, "Project-Based Learning in Engineering Education: Is it motivational?", International Journal of Engineering Education, vol.30(2), pp. 438-448, January 2014.

[25] B. Reynolds, M.M. Mehalik, M.R. Lovell and C.D. Schunn, "Increasing student awareness of and interest in engineering as a career option through design-based learning", International Journal of Engineering Education, vol.25(4), pp. 788, January 2009.

[26] M. Christie and T. Lucke, "Peer review in PBL: a comparative case study in problem and project based learning", Global Research Community: Collaboration and Developments, p. 468, 2015.

[27] M. Eliot and P. Howard, "Instructor's considerations for assessing individual students' learning in team-based coursework", Engineers Australia, pp.479, 2011.

[28] S. Chandrasekaran, A. Stojcevski, G. Littlefair and M. Joordens "Project-oriented design-based learning: aligning students' views with industry needs", International journal of engineering education, vol.29(5), pp. 1109-1118, March 2013.

[29] J.D. Lang, S. Cruse, F.D. McVey and J. McMasters, "Industry expectations of new engineers: A survey to assist curriculum designers", Journal of Engineering Education, vol.88(1), pp. 43-
51, January 1999. http://dx.doi.org/10.1002/j.2168-9830.1999. tb00410.x

[30] P. Howard, M.G. Rasul, and F. Nouwens, "Assessing final year engineering projects", PBL Across Cultures, pp. 95, 2013.

\section{AUTHORS}

Dr Sivachandran Chandrasekaran is a Research Fellow in Engineering Education at Deakin University (email: siva.chandrasekaran@deakin.edu.au). He has graduated his BE (CSE) in India and ME, MES (Electronics) from Victoria University and $\mathrm{PhD}$ (Engineering Education) from Deakin University respectively. $\mathrm{He}$ is active member of Deakin engineering education research Centre (DEERC), School of engineering in the Faculty of science, Engineering and Built Environment at Deakin University, Australia. He is an active researcher and his research interests include creativity and innovation in learning and teaching, Design based learning, Cloud learning \& located learning and engineering education innovation. His education philosophy is founded on the Project Oriented Design Based Learning (PODBL) approach at Deakin University.

Dr Riyadh Al-Ameri is a Fellow of the Institution of Engineers Australia and chartered Structural Engineer (email: r.alameri@deakin.edu.au). Since 2010, Al-Ameri is appointed as a Senior Lecturer at the School of Engineering, Deakin University. He have more than 25 years of mixed academic and industrial experience and involved significantly with academia, research, construction industry and consultations. He received his $\mathrm{BSc}$ in Civil Engineering from Baghdad University (IRAQ, 1982) and his MSc \& PhD in Structural Engineering from Cardiff University (UK, 1990). He has been appointed as Visiting Academic and Honorary Associate at the Civil Engineering Department, Monash University (2005), and Engineering Manager at international consultant (2006-2010). He obtained Endeavour Research Fellowship from the Australian Government (2005) and received Teaching Excellence Awards from Baghdad University, IRAQ (2001) and Deakin University, Australia (2012).

Submitted 09 January 2016. Published as resubmitted by the authors 23 March 2016.

\section{APPENDIX A- SURVEY QUESTIONS}

1. How comfortable do you feel practicing design based learning (DBL) approach in your unit?

2. Which design based learning mode do you prefer?

3. What is the level of satisfaction you have in DBL delivery in selected DBL mode?

4. How do you want to divide the contact hours between formal lectures and design class?

5. For partial DBL mode which one of these options do you prefer for assessment?

6. For full DBL mode which one of these options do you prefer for assessment?

7. Which one of these listed options do you prefer for project assessment?

8. Which one of these listed options do you prefer for grouping and how?

9. Which composition of group do you prefer with respect to off-campus and on-campus students?

10. Are you happy with your current group size?

11. How do you estimate your participation in a group task as $\%$ ?

12. Reason for your selection on question above? You may select more than one option

13. Do you think a group leader is essential for a group task?

14. What kind of role do you want take in a group?

15. Which group pattern helps you to develop learning objectives and benefits fro the task?

16. Do you prefer to share the task with your group/team members? 